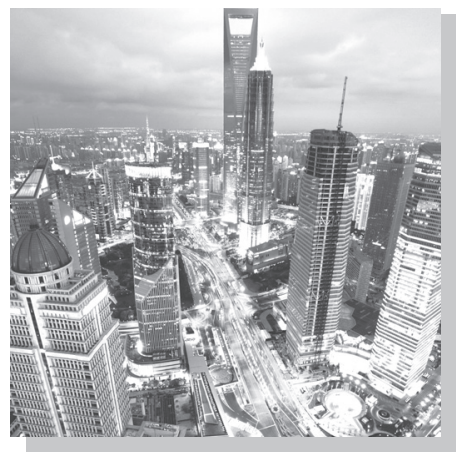

\title{
HANDBOOK OF CONTEMPORARY CHINA
}


This page intentionally left blank 


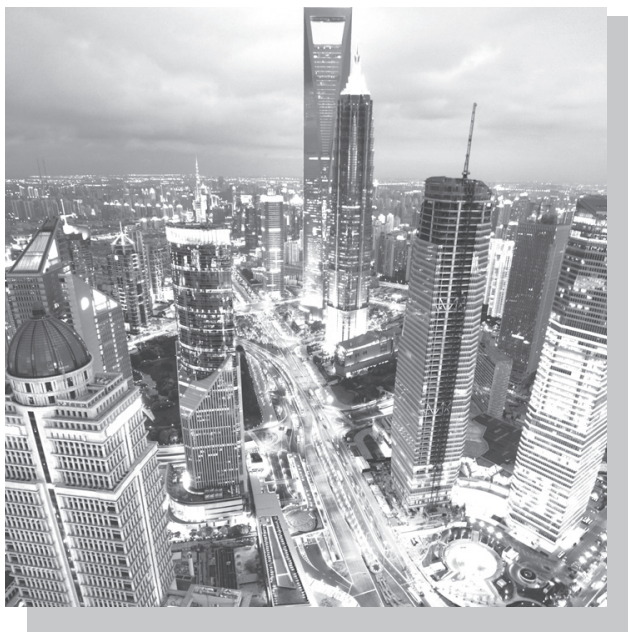

\title{
HANDBOOK OF CONTEMPORARY CHINA
}

\author{
edited by \\ William S Tay \\ Professor Emeritus \\ Hong Kong University of Science and Technology \\ and the University of California, San Diego \\ Alvin Y So \\ Chair Professor, Division of Social Science \\ Hong Kong University of Science and Technology
}




\section{Published by}

World Scientific Publishing Co. Pte. Ltd.

5 Toh Tuck Link, Singapore 596224

USA office: 27 Warren Street, Suite 401-402, Hackensack, NJ 07601

UK office: 57 Shelton Street, Covent Garden, London WC2H 9HE

\section{British Library Cataloguing-in-Publication Data}

A catalogue record for this book is available from the British Library.

\section{HANDBOOK OF CONTEMPORARY CHINA}

Copyright (C) 2012 by World Scientific Publishing Co. Pte. Ltd.

All rights reserved. This book, or parts thereof, may not be reproduced in any form or by any means, electronic or mechanical, including photocopying, recording or any information storage and retrieval system now known or to be invented, without written permission from the Publisher.

For photocopying of material in this volume, please pay a copying fee through the Copyright Clearance Center, Inc., 222 Rosewood Drive, Danvers, MA 01923, USA. In this case permission to photocopy is not required from the publisher.

ISBN-13 978-981-4350-08-2

ISBN-10 981-4350-08-7

Typeset by Stallion Press

Email: enquiries@stallionpress.com

Printed in Singapore. 


\section{PREFACE}

China launched its reform just over thirty years ago. No crystal ball then could have predicted its outcome. Titles of recent books such as China Rules the World: The End of the Western World and the Birth of a New Global Order and The Beijing Consensus: How China's Authoritarian Model Will Dominate the Twenty-First Century clearly confirm that China has finally arrived. Statistical projections from venerable institutions such as International Monetary Fund or Goldman Sachs appear to point toward a robust future: the former predicts that China's share of global GDP (in current prices) will pass the 10\% mark in 2013; and the latter that China will surpass the US in terms of GDP in 2027.

There are, however, several well-known Chinese sayings which remind us about the truism that to know the past is to know the future. It is with this in mind that we accepted the invitation from Dr. Lim Tai-Wei on behalf of World Scientific to organize a handbook on China's reform for a professional and general readership interested in visiting or revisiting the travails of the last thirty years.

William S. Tay Alvin Y. So

December, 2010 
This page intentionally left blank 


\section{CONTENTS}

Preface v

Willam S. TAY and Alvin Y. SO

1. Development Model

Alvin Y.SO

2. Politics

Kam-Yee LAW

3. Social Change

Xiaggang $W U$

4. Law

Bin LIANG

5. Population

Zhongdong $M A$

6. Ethnicity

Barry SAUTMAN

7. Foreign Policy

Simon SHEN

8. Environment

Yok-shiu LEE, Carlos Wing-hung LO

and Anna Ka-Yin LEE

9. Urbanization

Fulong $W U$

10. Higher Education

Ka-ho MOK and Li WANG 
viii Contents

11. Religion

David A. PALMER

12. Literature

Ling-tun NGAI

13. Cinema

Rui ZHANG

14. Consumption and Leisure

Kevin LATHAM

15. Internet and Civil Society

Guobin $\Upsilon A N G$

Index 